he discards the assumptions from the amended statement of the case, which he gives preparatory to a correct solution of it. The language quoted must therefore, I suppose, just be looked upon as an illustration of the vagueness of expression one is apt to fall into who commences writing on a subject which he has not fully considered in all its bearings.

Mr. Scratchley gives two correct solutions of the problem, as divested of the extraneous assumptions imported into it. The first, he says, is in accordance with " the ordinary mode of calculation." I suppose it is, where the use of Barrett's columns, with the facilities they afford, is eschewed. Bnt I doubt whether one person in ten of those into whose hands the tract will fall will understand that, by his periphrastic definition of " $A$ "-namely, the "accumnlated amount, with interest (by the end of the year when one [?] has died), of $£ 1$ a year, payable in advance, during the joint existence of $x, y$ "-he means simply, the assurance on $(x . y)$ that an annual preminm of $£ 1$ will provide.

Of his second solution Mr. S. says, that it is in a form which he believes is " not to be found in works on life contingencies." It may be so. Works on life contingencies do not profess to solve all the problems that may arise in practice, nor to give forms for their solution. What such works generally profess is, to lay down and exemplify principles; but the practical application of these is necessarily left to the judgment and intelligence of their readers.

The tract under consideration affords matter for further remark; but having exhausted my own time, your space, and, I fear, the patience of your readers, I must for the present forbear.

$$
\begin{aligned}
& \text { I am, Sir, } \\
& \text { Your most obedient Servant, }
\end{aligned}
$$

London, 13 th February, 1857.

G.

\title{
ON THE GRANT OF POLICIES WITHOUT FURTHER PAYMENT, IN CONSIDERATION OF PREMIUMS RECEIVED.
}

\section{To the Editor of the Assurance Magazine.}

SiR-It has been the practice of late years, with some of the Life Insurance Offices, when the assured is nuable to continue his payments on an ordinary policy, to offer him, in exchange, a policy of a smaller amount, free from all future payments-or, a "paid-np" policy. More recently, the amount of this paid-up policy has been fixed by a new Office (the Unity) as equal to the amount of the premiums that have been paid on the policy, so that the representatives of the assured will receive back the amount that has been paid to the Office. As this is a plan that is likely to be pleasing to the public, from the eircumstances of its being so readily understood, and carrying with it the appearance of equity, it will be interesting to examine in some detail its operation in practice.* We can very readily find a simple expression for the amount of the paid-up poliey that may be given in exchange for the surrender of an ordinary policy after the lapse of any number of years. Thus, suppose that a policy, taken out at the age $m$, has been in force $n$ years, the preminm being just due and not paid; also, as usual, let $a_{m}, \mathrm{~A}_{m}$, denote the values of an annuity and an assurance of $£ 1$ on a life aged $m$; also, $\mathbf{P}_{m}$ the annual preminm for an ordinary assur-

* There are two letters on this subject in the Post Magazine for October, 1855, bat they take only a partial view of the question. 
ance of $£ 1$ on the same life. Then the surrender value of the policy is $\Sigma=\mathrm{A}_{m+n}-\left(1+a_{m+n}\right) \mathrm{P}_{m}$, and the amount of the paid-up policy will be $\frac{\Sigma}{\mathbf{A}_{m+n}}$, or $1-\frac{1+a_{m+n}}{\mathbf{A}_{m+n}}, \mathbf{P}_{m}$. Bnt $\frac{\mathbf{A}_{m+n}}{1+a_{m+n}}=\mathbf{P}_{m+n}$-the annual premium for assurance at age $m+n$, whence the amount of the paid-up policy is $1-\frac{\mathbf{P}_{m}}{\mathbf{P}_{m+n}}$. In obtaining this expression, the full surrender value of the policy has been taken; no charge having been made to the assured on account of the expenses of conducting the Office, although his name still remains on its books. If the sum originally assured is $\mathrm{S}$, the amount of the paid-up poliey will be $\mathrm{S}\left(1-\frac{\mathrm{P}_{m}}{\mathrm{P}_{n+n}}\right)$. This formula expresses that the sum assured is to be dimmished by a quantity that bears the same ratio to it that the original premium does to the preminm at the increased age-i.e., by the amount which the original preminm will insure at the increased age, neglecting here the additions made to the net preminus for the expenses, \&c. If the preminms charged differ from the net premiums by a constant percentage, the value of the paid-up policy given by the formula will coincide in practice with the rule just stated.

By means of the formula above, the values in the following table have been calculated; and by tabulating the values of $\frac{1}{P_{20}}, \frac{1}{P_{25}}$, \&c. from a table of reciprocals, the calculation is made with very great ease and rapidity. The table of mortality used is the Experience, with interest at 3 per cent.

Table showing the Amount of Assurance which may be granted in consideration of the Surrender of an Ordinary Policy for $\$ 100$ after the lapse of a given number of Years.

\begin{tabular}{|c|c|c|c|c|c|c|c|c|c|c|c|c|}
\hline \multirow{2}{*}{ 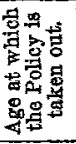 } & \multicolumn{12}{|c|}{ Amount of Paid-np Poliey at the end of } \\
\hline & $\begin{array}{c}5 \\
\text { Years }\end{array}$ & $\begin{array}{c}10 \\
\text { Years. }\end{array}$ & $\begin{array}{c}15 \\
\text { Yeara }\end{array}$ & $\begin{array}{c}20 \\
\text { Years. }\end{array}$ & $\begin{array}{c}25 \\
\text { Years }\end{array}$ & $\begin{array}{c}30 \\
\text { Years }\end{array}$ & $\begin{array}{c}35 \\
\text { Years }\end{array}$ & $\begin{array}{c}40 \\
\text { Years. }\end{array}$ & $\begin{array}{c}45 \\
\text { Year }\end{array}$ & $\begin{array}{c}50 \\
\text { Years }\end{array}$ & $\begin{array}{c}55 \\
\text { Yeara }\end{array}$ & $\begin{array}{c}60 \\
\text { Years. }\end{array}$ \\
\hline 20 & $\begin{array}{r}11-5 \\
7 \times 8\end{array}$ & $\begin{array}{l}22 \cdot 7 \\
155\end{array}$ & $\begin{array}{l}33 * 4 \\
23 * 3\end{array}$ & $\begin{array}{l}43 \cdot 5 \\
31 \cdot 1\end{array}$ & $\begin{array}{l}53 \cdot 0 \\
38 \cdot 9\end{array}$ & $\begin{array}{l}61 \cdot 6 \\
46 \cdot 6\end{array}$ & $\begin{array}{l}69 \cdot 1 \\
54^{*} 4\end{array}$ & $\begin{array}{l}75 \cdot 6 \\
62+2\end{array}$ & $\begin{array}{l}81 \cdot 0 \\
69^{\circ} 9\end{array}$ & $\begin{array}{l}85 * 4 \\
77 * 7\end{array}$ & $\begin{array}{l}890 \\
855\end{array}$ & $\begin{array}{l}91 \cdot 8 \\
93^{\circ} 2\end{array}$ \\
\hline 30 & $\begin{array}{l}13+8 \\
10 \% 0\end{array}$ & $\begin{array}{l}26 * 9 \\
19 * 9\end{array}$ & $\begin{array}{l}39 \cdot 2 \\
29 \% 9\end{array}$ & $\begin{array}{l}50 \cdot 3 \\
39^{-8}\end{array}$ & $\begin{array}{l}60 \cdot 0 \\
49^{\circ} 8\end{array}$ & $\begin{array}{l}68 \cdot 4 \\
59^{\circ} 8\end{array}$ & $\begin{array}{l}75 * 4 \\
69^{*} 7\end{array}$ & $\begin{array}{l}81 \cdot 1 \\
79 \% 7\end{array}$ & $\begin{array}{l}85 \cdot 7 \\
89^{6} 6\end{array}$ & $\begin{array}{l}89^{\circ} 4 \\
99^{\circ} 6\end{array}$ & & \\
\hline 40 & $\begin{array}{l}16.9 \\
135\end{array}$ & $\begin{array}{l}32 \cdot 1 \\
26 \cdot 9\end{array}$ & $\begin{array}{l}45 \cdot 4 \\
40^{\prime} 4\end{array}$ & $\begin{array}{l}56.8 \\
53.8\end{array}$ & $\begin{array}{l}66 \cdot 4 \\
673\end{array}$ & $\begin{array}{l}74 \cdot 2 \\
80 \cdot 8\end{array}$ & $\begin{array}{l}60 \cdot 5 \\
94^{2}\end{array}$ & $\begin{array}{r}856 \\
1077\end{array}$ & & & & \\
\hline 50 & $\begin{array}{l}19 \cdot 6 \\
197\end{array}$ & $\begin{array}{l}36^{\circ} \cdot 3 \\
39^{\circ} 4\end{array}$ & $\begin{array}{l}50 \cdot 5 \\
59^{\circ} 1\end{array}$ & $\begin{array}{l}62 \cdot 0 \\
78.8\end{array}$ & $\begin{array}{l}71 \cdot 3 \\
98 \cdot 6\end{array}$ & $\begin{array}{r}78 \cdot 6 \\
1 \leq 8.3\end{array}$ & & & & & & \\
\hline 60 & $\begin{array}{l}22-2 \\
3^{1 * 3}\end{array}$ & $\begin{array}{l}40 \cdot 3 \\
62 * 5\end{array}$ & $\begin{array}{l}54 \cdot 9 \\
93 \cdot 8\end{array}$ & $\begin{array}{r}66^{\circ} 4 \\
125^{\prime} I\end{array}$ & & & & & & & & \\
\hline
\end{tabular}

Nors.-For the sake of comparison, the amounts of the premiums paid, by the Unity non-participating rates, are inserted in the above table; being placed below the amomt of the corresponding paid-up policy, in a different type.

This table may be read as follows:-If a policy for $£ 100$ is taken out on the non-participating scale (at the age 20), then, after the lapse of five years, the full amount of the equivalent paid-up policy is $£ 11.5$, and the 
Unity will give a policy for $£ 7 \cdot 8$; after forty years, the full amount of the paid-up policy is $\mathbf{E} 75^{\circ} \mathbf{6}$, and the Unity will give a policy for $\mathbf{E} 62 \cdot 2$; and similarly for the other cases. In each of the five cases considered, the amount of the paid-up policy has been calculated at intervals of five years; and in every instance, till the age of the life assured reaches 80 , it has been thought unnecessary to proceed further than this, since the number of those who survive this age is so small comparatively that the Office is not likely to be affected to any sensible extent by any conrse the survivors may pursue. The non-participating rates are taken because the difference between the preminms paid on the participating and non-participating scales will most likely be at least equalled by the bonuses declared upon the former supposition.

From this table it is obvious, that in the first case, when the policy is taken out at the age 20 , the Office is secure from loss for nearly sixty years: the deduction that is made from the full value of the policy, on the plan supposed, being nearly one third at the end of five years, and gradnally diminishing as the age of the policy increases. When the policy is taken out at 30 , the advantage is on the side of the Office for forty years; and for twenty years when the policy is taken ont at 40 . Also, supposing the Office to make on the average 4 per cent. on its investments (which seems to be the rate generally realized), since the above calculations have been made on the supposition of interest at 3 per cent., in a long course of years the difference between these rates will accumulate, and diminish the loss that the Office will sustain at the advanced ages. Thus far, then, the plan under consideration will in no case canse a serious loss to the Office; thongh, at the older ages, it allows a small and a diminishing margin for profit. But the case is altered when we come to consider policies taken out at 50 , and higher ages. In these there is a loss to the Office from the commencement, increasing with the age of the policy. At the age of 60 , the loss after five years amounts to nearly 50 per cent.; and if assurances at these advanced ages were common in the Office, it is clear that a very serions loss might be entaled on it.

One effect of the plan adopted by the Unity will be, that the Office may sustain a loss as follows:--Suppose that a person assured his life for

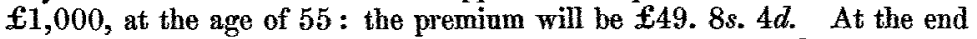
of five years the Offee will give bim a paid-up policy for $£ 246.1 s .8 d$. At his increased age of 60 the original preminm will insure $f 790$ : thns he will now be insured for $£ 1,036$, instead of $£ 1,000$ as previonsly. The pnblished rates of the Unity do not give the premiums for ages above 60; but if the second assurance were made at 65 or 70 , the effect just indicated would be considerably increased.

We might anticipate the general results indicated by the table from the considerations that the full surrender valne of a policy is, in general, abont two thirds of the preminms paid; and that the ratio of a single premium to the amount it will insure is about $1: 2$ at the age 40 , and $2: 3$ at 60 .

$$
\text { I am, Sir, }
$$

Eagle Insurance Company, Your obedient Servant, 28 February, 1857.

\section{T. B. SPRAGUE.}

P.S. If interest is assumed at the rate of 4 per cent., the amount of the paid-np policy will be larger than that given in the table, bat the difference is comparatively small. 